\title{
Pseudoxanthomonas kalamensis sp. nov., a novel gammaproteobacterium isolated from Johnston Atoll, North Pacific Ocean
}

Correspondence
Qing X. Li
qingl@hawaii.edu

Johnston Atoll is located in the North Pacific Ocean $\left(16^{\circ} 45^{\prime}\right.$ $\left.\mathrm{N}, 169^{\circ} 31^{\prime} \mathrm{W}\right), 717$ miles south-west of Honolulu, Hawaii. The atoll has been a designated wildlife refuge since 1926 and has been under the control of the US military since 1934. The site was used for high-altitude nuclear tests in the 1950s and 1960s, and, until late in 2000, as a storage and disposal site for chemical weapons. Operation of the chemical disposal facility has ceased and the decommissioning, dismantling and clean-up of the site was completed in 2003.

The genera Stenotrophomonas, Xanthomonas and Pseudoxanthomonas partly comprise the family Xanthomonadaceae in the Gammaproteobacteria (Finkmann et al., 2000; Yang et al., 2005). These genera share phenotypic traits (e.g. colony shape and colour, cell morphology, Gram reaction), the presence of branched-chain fatty acids and the presence of ubiquinones with eight isoprenoid units (Q-8). Members of the genus Pseudoxanthomonas, however, are differentiated from members of the genera Xanthomonas and Stenotrophomonas by their ability to reduce nitrite but not nitrate to $\mathrm{N}_{2} \mathrm{O}$ and by the absence of the fatty acid $\mathrm{C}_{13: 0}$ iso $3-\mathrm{OH}$ (Thierry et al., 2004). Here we describe the isolation of strain

The GenBank/EMBL/DDBJ accession number for the $16 \mathrm{~S}$ rRNA gene sequence of strain $\mathrm{JA}_{4}{ }^{\top}$ is $\mathrm{AY} 686710$.

A transmission electron micrograph of strain $\mathrm{JA} 4 \mathrm{O}^{\top}$ and a table comparing the fatty acid content of strain $\mathrm{JA}_{4} \mathrm{O}^{\top}$ with that of other Pseudoxanthomonas species are available as supplementary material in IJSEM Online.
$\mathrm{JA} 40^{\mathrm{T}}$ and its characterization as a novel species of the genus Pseudoxanthomonas.

Strain JA40 ${ }^{\mathrm{T}}$ was isolated from soil contaminated with polycyclic aromatic hydrocarbons and polychlorinated biphenyls from Johnston Atoll. The strain was originally cultivated from serial dilutions of soil spread-plated on marine agar 2216 (MA; Difco). Colonies that arose after 3-5 days incubation at $30^{\circ} \mathrm{C}$ were streaked for isolation on MA. Strain purity was checked (through repeated transfers) by assessing the consistency of the colony characteristics, the cell morphology and the Gram reaction. Strain JA40 ${ }^{\mathrm{T}}$ was maintained on MA or in marine broth 2216 (MB; Difco). Stock cultures were stored at $-80{ }^{\circ} \mathrm{C}$ in $\mathrm{MB}$ with $50 \%(\mathrm{v} / \mathrm{v})$ glycerol.

Unless noted, all characterizations of strain JA40 ${ }^{\mathrm{T}}$ were performed on cells grown for 5 days at $30^{\circ} \mathrm{C}$ on MA. Motility was checked by means of the hanging drop method using light microscopy under a $\times 100$ objective with oil immersion. The morphology of negatively stained cells ( $1 \%$ uranyl acetate) was observed in an LEO 912 energy-filtering transmission electron microscope. Images were recorded as digital files with a Pro-scan frame transfer CCD camera. Cells prepared for transmission electron microscopy were grown for 4 days on tryptic soy agar (TSA; Difco) and resuspended in $0.85 \%$ $(\mathrm{w} / \mathrm{v})$ sterile saline. For negative staining, $10 \mu \mathrm{l}$ resuspended cells was placed on a 400-mesh Formvar-coated grid and stained with $1 \%$ uranyl acetate ( $\mathrm{pH} 4)$. Single colonies were tested for catalase with $3 \%(\mathrm{v} / \mathrm{v}) \mathrm{H}_{2} \mathrm{O}_{2}$ (Sigma) and for oxidase with tetramethyl- $p$-phenylenediamine on paper discs 
(BBL). The growth temperature range was determined from 4 to $40{ }^{\circ} \mathrm{C}$ on MA. The salinity tolerance was measured by growth as a function of turbidity in tryptic soy broth (TSB) diluted to $50 \%$ of the original concentration, supplemented with $\mathrm{NaCl}$ at final concentrations in the range $0 \cdot 5-8 \%(\mathrm{w} / \mathrm{v})$. The $\mathrm{OD}_{650}$ was measured after 5 days incubation with shaking (130 r.p.m.) at $30^{\circ} \mathrm{C}$. The presence or absence of constitutive enzymes was checked using API ZYM (bioMérieux) and the profile of substrates used was obtained by using API 20NE (bioMérieux). Additionally, the oxidation of carbon substrates was determined with Biolog GN/GP microplates.

Genomic DNA was isolated from a 5-day culture in $\mathrm{MB}$ by using a phenol/chloroform extraction of pelleted cells (Marmur, 1961). A fragment of the 16S rRNA gene was amplified from the genomic DNA (100-200 $\mathrm{ng}^{-1} \mathrm{l}^{-1}$ ) by means of a PCR with Ex-Taq DNA polymerase (Takara Mirus Bio) and primers 27F and 1492R (Lane, 1991). The PCR product was purified using the Ultraclean PCR purification kit (Mo Bio Lab) and sequenced in both directions in an Applied Biosystems 377XL DNA sequencer. The 16S rRNA gene sequences were manually edited and assembled in SEQUENCHER and SEQMAN (Lasergene). Assembled sequences were compared with those in the public domain through a BLASTN search (Altschul et al., 1997). The phylogenetic relationships between $\mathrm{JA} 40^{\mathrm{T}}$ and type strains in the genera Pseudoxanthomonas, Stenotrophomonas, Xanthomonas and Xylella were determined on the basis of comparative $16 \mathrm{~S}$ rRNA gene sequence analysis. These analyses were performed with programs in the PHYLIP 3.63 package (Felsenstein, 2004). Evolutionary distances were calculated using the maximumlikelihood method with DNADIST. For bootstrap analyses based on 100 replicates, SEQBOOT, DNADIST and CONSENSE were used. Phylogenetic trees were constructed using DNAML with jumbled orders of the sequences and the neighbour-joining method (Saitou \& Nei, 1987). Genomic DNA from strain $\mathrm{JA}_{40}{ }^{\mathrm{T}}$ was hybridized with DNA from Pseudoxanthomonas broegbernensis DSM $12573^{\mathrm{T}}$ by the Deutsche Sammlung von Mikroorganismen und Zellkulturen (Braunschweig, Germany). DNA was isolated using a French pressure cell (Thermo Spectronic) and purified by chromatography on hydroxyapatite as described by Cashion et al. (1977). DNADNA hybridization was carried out as described by De Ley et al. (1970), with modifications described by Huß et al. (1983), in a Cary 100 Bio UV/VIS-spectrophotometer equipped with a Peltier-thermostat $6 \times 6$ multicell changer and temperature controller with an in situ temperature probe (Varian). The determination of the $\mathrm{G}+\mathrm{C}$ content of strain JA $40^{\mathrm{T}}$ was also performed by the Deutsche Sammlung von Mikroorganismen und Zellkulturen using HPLC as described by Mesbah et al. (1989) and Tamaoka \& Komagata (1984). Fatty acid methyl ester analysis was performed by MIDI Labs on whole cells grown on TSA incubated at $28^{\circ} \mathrm{C}$ for $24 \pm 2 \mathrm{~h}$ according to Sasser (1997). Quinones were extracted from fresh cells of strain $\mathrm{JA} 40^{\mathrm{T}}$ by using a mixture of chloroform and methanol $(2: 1, \mathrm{v} / \mathrm{v})$ (Hiraishi, 1988). The extracts were filtered and evaporated to near dryness. The residue was redissolved in acetone prior to LC-MS analysis. An Agilent 1100 series liquid chromatograph equipped with a diode array detector and an MSD SL model mass spectrometer was used for the negativemode electrospray analysis.

Denitrification reactions were investigated using strain JA40 ${ }^{\mathrm{T}}$ grown in Hungate tubes (Bellco) in TSB supplemented with either $10 \mathrm{mM} \mathrm{Na}\left({ }^{15} \mathrm{NO}_{3}^{-}\right)$or $10 \mathrm{mM} \mathrm{Na}\left({ }^{15} \mathrm{NO}_{2}^{-}\right)$(Isotec). The medium was pre-reduced by purging the hermetically sealed tubes with oxygen-free nitrogen gas prior to sterilization. Inoculated tubes were incubated for 7 days at $30^{\circ} \mathrm{C}$ without shaking. Reduction of nitrate was determined by the traditional colorimetric method of adding sulfanilic acid, $N, N$-dimethyl-1-naphthylamine and zinc powder (as required) to the culture medium after incubation (Smibert \& Krieg, 1994). Additionally, gas samples from the headspace were collected and analysed by using a GC-MS method similar to the one described by Finkmann et al. (2000). GCMS analysis was performed with a CP 3800 gas chromatograph interfaced with a 1200 quadrupole mass spectrometer (Varian). The injector temperature was kept at $100{ }^{\circ} \mathrm{C}$, the GC oven at $50{ }^{\circ} \mathrm{C}$, the GC-MS transfer line at $200^{\circ} \mathrm{C}$ and the source at $250^{\circ} \mathrm{C}$. The GC-MS was performed using apparatus in electron-impact mode at $70 \mathrm{eV}$; full scans were acquired and the molecular ions for ${ }^{15} \mathrm{NO}, 31^{+},{ }^{14,15} \mathrm{~N}_{2} \mathrm{O}$, $45^{+}$, and ${ }^{15,15} \mathrm{~N}_{2} \mathrm{O}, 46^{+}$, were monitored.

The cells of strain $\mathrm{JA} 40^{\mathrm{T}}$ are single, straight rods $0 \cdot 5 \times$ $\sim 1 \cdot 0-1 \cdot 25 \mu \mathrm{m}$ in size. The strain grows slowly on MA at 28,30 and $37^{\circ} \mathrm{C}$, but there is no growth at 4 or $40{ }^{\circ} \mathrm{C}$. Colonies are small $(1-1.5 \mathrm{~mm})$, shiny, pale yellow in colour and circular after $4-5$ days on MA at 30 and $37^{\circ} \mathrm{C}$. On TSA, however, colonies are darker yellow and circular, but still small $(1-1.5 \mathrm{~mm})$. The strain grows at salinities in the range $0 \cdot 5-3 \%(\mathrm{w} / \mathrm{v}) \mathrm{NaCl}$ in $50 \%$ TSB with optimal growth in the presence of $2 \%(\mathrm{w} / \mathrm{v}) \mathrm{NaCl}$. Strain $\mathrm{JA}_{40}{ }^{\mathrm{T}}$ is nonsporulating and non-motile. Transmission electron microscopy revealed the absence of flagella (see Supplementary Fig. S1 in IJSEM Online). All other Pseudoxanthomonas spp. have a single polar flagellum, with the exception of Pseudoxanthomonas koreensis KCTC $12208^{\mathrm{T}}$ and the thermophile Pseudoxanthomonas taiwanensis ATCC BAA$404^{\mathrm{T}}$ (Theirry et al., 2004; Chen et al., 2002; Yang et al., 2005). The constitutive enzyme activities expressed in API ZYM tests included alkaline phosphatase, esterase, esterase lipase, leucine arylamidase, valine arylamidase, cystine arylamidase, trypsin, $\alpha$-chymotrypsin, acid phosphatase, naphthol-AS-BI-phosphohydrolase, $\beta$-glucosidase and $N$ acetyl- $\beta$-glucosamidase. Comparisons of the physiological characteristics of $\mathrm{JA}_{4} 0^{\mathrm{T}}$ with those of related Pseudoxanthomonas species, based on API 20NE tests, are listed in Table 1. Like all other Pseudoxanthomonas species, except Pseudoxanthomonas taiwanensis (for which there are no data), strain $J \mathrm{~A} \mathrm{O}^{\mathrm{T}}$ is unable to assimilate caprate, adipate or phenylacetate.

The fatty acids comprising more than $5 \%$ of the total in $\mathrm{JA}^{\mathrm{T}}{ }^{\mathrm{T}}$ are as follows: $11: 0$ iso $(6 \cdot 87 \%), 11: 0$ iso $3-\mathrm{OH}$ $(8 \cdot 32 \%), 15: 0$ iso $(40 \cdot 02 \%), 16: 0$ iso $(6 \cdot 85 \%), 17: 0$ iso $(6 \cdot 68 \%)$ and $17: 1$ iso cis7 $(9 \cdot 04 \%)$. Smaller amounts of 
Table 1. Characteristics, based on API $20 \mathrm{NE}$ tests, that differentiate strain $\mathrm{JA} 40^{\top}$ from other Pseudoxanthomonas species

Strains: 1, Pseudoxanthomonas kalamensis sp. nov. JA40 ${ }^{\mathrm{T}}$; 2, Pseudoxanthomonas broegbernensis DSM 12573 ${ }^{\mathrm{T}}$ (Thierry et al., 2004); 3 , Pseudoxanthomonas mexicana DSM $15133^{\mathrm{T}}$ (Thierry et al., 2004); 4, Pseudoxanthomonas japonensis JCM 11525 ${ }^{\mathrm{T}}$ (Thierry et al., 2004); 5, Pseudoxanthomonas taiwanensis ATCC BAA-404 ${ }^{\mathrm{T}}$ (Chen et al., 2002); 6, Pseudoxanthomonas koreensis KCTC 11208 ${ }^{\mathrm{T}}$ (Yang et al., 2005); 7 , Pseudoxanthomonas daejeonensis KCTC $12207^{\mathrm{T}}$ (Yang et al., 2005); 8, Pseudoxanthomonas kaohsiungensis LMG 22530 ${ }^{\mathrm{T}}$ (Chang et al., 2005). ND, No data available.

\begin{tabular}{|c|c|c|c|c|c|c|c|c|}
\hline Characteristic & 1 & 2 & 3 & 4 & 5 & 6 & 7 & 8 \\
\hline Optimum growth temp. $\left({ }^{\circ} \mathrm{C}\right)$ & $30-37$ & 30 & $30-37$ & $30-37$ & 50 & 30 & 30 & 35 \\
\hline Catalase & + & + & + & - & + & + & + & - \\
\hline$\beta$-Galactosidase & - & + & - & + & + & - & + & + \\
\hline$\beta$-Glucosidase & + & - & + & + & + & - & + & + \\
\hline Urease & - & - & - & - & ND & + & - & - \\
\hline Arginine dihydrolase & - & - & - & - & $\mathrm{ND}$ & + & - & - \\
\hline \multicolumn{9}{|l|}{ Carbon-substrate assimilation } \\
\hline D-Glucose & + & + & + & + & + & - & + & + \\
\hline L-Arabinose & + & + & - & - & - & - & + & - \\
\hline Malate & - & - & - & + & - & - & - & - \\
\hline Citrate & - & + & - & - & ND & - & - & - \\
\hline DNA G $+C$ content $(\mathrm{mol} \%)$ & 64 & $66 \cdot 5 \pm 0 \cdot 8$ & $67 \cdot 8 \pm 2$ & $65 \cdot 5 \pm 1$ & $69 \cdot 9-70 \cdot 1$ & $69 \cdot 5$ & $68 \cdot 7$ & $60 \cdot 1$ \\
\hline
\end{tabular}

$15: 0$ anteiso $(4 \cdot 61 \%), 16: 0(2 \cdot 92 \%), 16: 1$ cis 10 alcohol $(1 \cdot 92 \%), 16: 1$ cis5 $(1 \cdot 21 \%)$ and $17: 0$ anteiso $(1 \cdot 84 \%)$ are present. The fatty acids that distinguish strain $\mathrm{JA} 40^{\mathrm{T}}$ from other Pseudoxanthomonas species are listed in Supplementary Table S1 (available in IJSEM Online) and include $12: 0$ iso $3-\mathrm{OH}, 15: 1$ cis9, 16:1 cis5 and 16:1 cis9 alcohol, and larger amounts of $11: 0$ iso and $11: 0$ iso $3-\mathrm{OH}$.

The GC-MS analysis confirmed that strain $\mathrm{JA}_{40}{ }^{\mathrm{T}}$ reduced $\mathrm{NO}_{2}^{-}$but not $\mathrm{NO}_{3}^{-}$, under the conditions tested. Upon reduction of $\mathrm{NO}_{2}^{-}$, supplied as $\mathrm{Na}\left({ }^{15} \mathrm{NO}_{2}^{-}\right)$, the only product found was ${ }^{15,15} \mathrm{~N}_{2} \mathrm{O}$ as the ion $46^{+}$. It was not determined in this study whether nitrous oxide was the sole and final product of the nitrite reduction. Similar results have been observed for all other Pseudoxanthomonas species, except Pseudoxanthomonas koreensis KCTC $12208^{\mathrm{T}}$ and Pseudoxanthomonas daejeonensis KCTC $12207^{\mathrm{T}}$. On the basis of $16 \mathrm{~S}$ rRNA gene nucleotide sequences, the closest relatives of strain $\mathrm{JA}^{\mathrm{T}} \mathrm{T}^{\mathrm{T}}$ are Pseudoxanthomonas species (Fig. 1). In fact, strain $\mathrm{JA}_{4}{ }^{\mathrm{T}}$ shares $95 \cdot 5 \%$ sequence identity with Pseudoxanthomonas broegbernensis DSM $12573^{\mathrm{T}}, 96 \cdot 1 \%$ with Pseudoxanthomonas japonensis CIP $107388^{\mathrm{T}}$, 96.1\% with Pseudoxanthomonas daejeonensis KCTC $12207^{\mathrm{T}}$, $95 \cdot 7 \%$ with Pseudoxanthomonas koreensis KCTC $12208^{\mathrm{T}}$ and $96 \cdot 3 \%$ with Pseudoxanthomonas mexicana ATCC $700999^{\mathrm{T}}$ (in each case determined over more than $1400 \mathrm{nt}$ ). The level of DNA-DNA reassociation between genomic DNA from strain $\mathrm{JA}_{4} 0^{\mathrm{T}}$ and that from the Pseudoxanthomonas type species, Pseudoxanthomonas broegbernensis DSM $12573^{\mathrm{T}}$, was $40 \cdot 4 \%$, which is sufficient to distinguish $\mathrm{JA}_{40}{ }^{\mathrm{T}}$ from Pseudoxanthomonas broegbernensis according to the recommendation of the ad hoc committee on bacterial systematics (Wayne et al., 1987). The $\mathrm{G}+\mathrm{C}$ content for strain $\mathrm{JA} 40^{\mathrm{T}}$ is $64 \mathrm{~mol} \%$. On the basis of the morphological characteristics, 16S rRNA gene sequence, physiology, unique fatty acid composition and denitrification reaction of strain $\mathrm{JA} 40^{\mathrm{T}}$, it represents the type strain of a novel species of the genus Pseudoxanthomonas, for which we propose the name Pseudoxanthomonas kalamensis sp. nov.

\section{Description of Pseudoxanthomonas kalamensis sp. nov.}

Pseudoxanthomonas kalamensis (ka.lam.en'sis. N.L. fem. adj. kalamensis of Kalama Island, referring to the Hawaiian name for Johnston Atoll, where the organism was isolated).

Aerobic. Yellow colonies form on heterotrophic media after 4-5 days (e.g. TSA, MA). Cells are Gram-negative, single, straight rods $1 \cdot 0-1 \cdot 25 \mu \mathrm{m}$ in length and $0.5 \mu \mathrm{m}$ in width. Non-motile. Mesophilic, with an optimum temperature range of $30-37^{\circ} \mathrm{C}$. Cytochrome oxidase- and catalase-positive. Negative for $\beta$-galactosidase (ONPG hydrolysis) and positive for $\beta$-glucosidase (aesculin hydrolysis). The spectra of substrates utilized is presented in Table 1. Additionally, strain $\mathrm{JA}_{40}{ }^{\mathrm{T}}$ oxidizes diverse carbon sources available in Biolog GN and GP, namely $\alpha$-cyclodextrin, $\beta$-cyclodextrin, dextrin, 


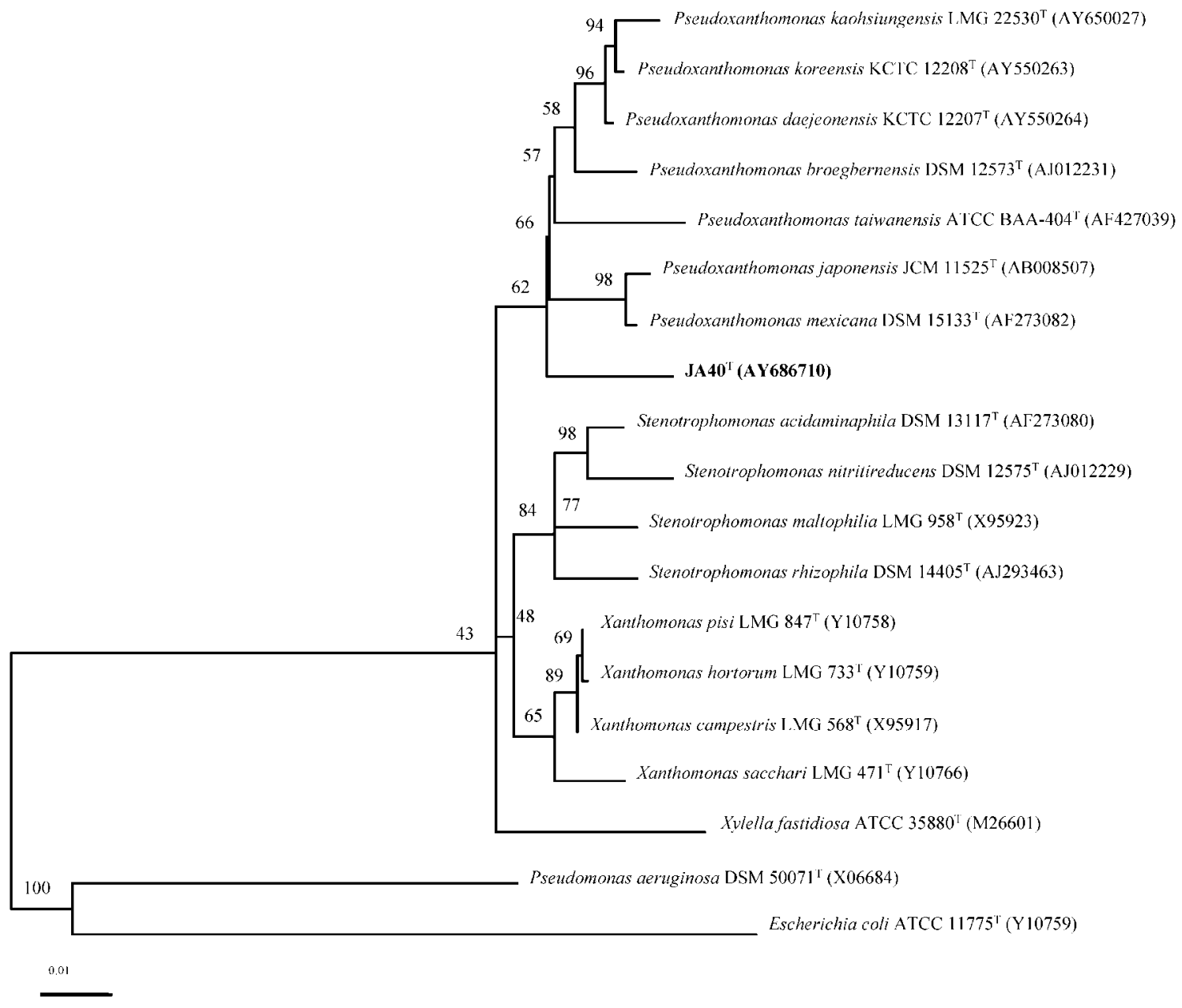

Fig. 1. Neighbour-joining tree, based on nearly complete $16 \mathrm{~S}$ rRNA gene sequences, showing relationships between strain $\mathrm{JA} 40^{\top}$ and members of the Xanthomonadaceae. Numbers at the nodes are bootstrap percentages based on maximumlikelihood analyses of 100 resampled datasets. Escherichia coli ATCC $11775^{\top}$ and Pseudomonas aeruginosa DSM 50071 were used as outgroups. Bar, 0.01 nucleotide substitutions per site.

glycogen, mannan, Tween 80 , amygdalin, arbutin, D-cellobiose, D-fructose, gentiobiose, $\alpha$-D-glucose, myo-inositol, maltose, maltotriose, D-mannose, D-melezitose, methyl $\alpha$-Dgalactoside, methyl $\alpha$-D-glucoside, methyl $\beta$-D-glucoside, D-raffinose, salicin, sucrose, D-trehalose, turanose, $\beta$-hydroxybutyric acid, D-malic acid, succinic acid monomethyl ester, succinamic acid, $\mathrm{N}$-acetyl-L-glutamic acid, L-alaninamide, Dalanine, L-alanine, L-alanyl glycine, L-glutamic acid, glycyl Lglutamic acid, L-serine, D-fructose 6-phosphate, $\alpha$-D-glucose 1-phosphate, D-glucose 6-phosphate and D-lactic acid methyl ester. The DNA G + C content is $64 \mathrm{~mol} \%$. The predominant fatty acids are 15:0 iso, 17:1 iso cis7 and 11:0 iso $3-\mathrm{OH}$. Nitrite is reduced, with the production of nitrous oxide as a main product; nitrate is not reduced.

The type strain, $\mathrm{JA} 40^{\mathrm{T}}\left(=\mathrm{ATCCBAA}-1031^{\mathrm{T}}=\mathrm{CIP} 108476^{\mathrm{T}}\right)$, was isolated from soil contaminated with polycyclic aromatic hydrocarbons and polychlorinated biphenyls collected from Johnston Atoll in the North Pacific Ocean.

\section{Acknowledgements}

This work was supported by a US-EPA award (X989512-01-1), a USDA-TSTAR award (0034135-9576) and contractual agreements with the US Fish and Wildlife Service (USFWS) and the State of Hawaii Department of Health (Office of Hazard Evaluation and Emergency Response). We thank Mark Ingoglia of the US Air Force (Pacific Region) and Dr LeeAnn Woodward of USFWS for sample collection, Tina Carvalho for transmission electron microscopy work, and Dr Jean Euzéby for assistance with Latin grammar. We are indebted to Dr Stuart P. Donachie, Dr Sarah A. Lorenz Caccamise and Dr Michael J. Cooney for helpful discussions.

\section{References}

Altschul, S. F., Madden, T. L., Schäffer, A. A., Zhang, J., Zhang, Z., Miller, W. \& Lipman, D. J. (1997). Gapped BLAST and PSI-BLAST: a new generation of protein database search programs. Nucleic Acids Res 25, 3389-3402. 
Cashion, P., Holder-Franklin, M. A., McCully, J. \& Franklin, M. (1977). A rapid method for the base ratio determination of bacterial DNA. Anal Biochem 81, 461-466.

Chang, J.-S., Chou, C.-L., Lin, G.-H., Sheu, S.-Y. \& Chen, W.-M. (2005). Pseudoxanthomonas kaohsiungensis, sp. nov., a novel bacterium isolated from oil-polluted site produces extracellular surface activity. Syst Appl Microbiol 28, 137-144.

Chen, M.-Y., Tsay, S.-S., Chen, K.-Y., Shi, Y.-C., Lin, Y.-T. \& Lin, G.-H. (2002). Pseudoxanthomonas taiwanensis sp. nov., a novel thermophilic, $\mathrm{N}_{2} \mathrm{O}$-producing species isolated from hot springs. Int J Syst Evol Microbiol 52, 2155-2161.

De Ley, J., Cattoir, H. \& Reynaerts, A. (1970). The quantitative measurement of DNA hybridization from renaturation rates. Eur J Biochem 12, 133-142.

Felsenstein, J. (2004). PHYLIP (phylogeny inference package), version 3.63. Distributed by the author. Department of Genome Sciences, University of Washington, Seattle, USA.

Finkmann, W., Altendorf, K., Stackebrandt, E. \& Lipski, A. (2000). Characterization of $\mathrm{N}_{2} \mathrm{O}$-producing Xanthomonas-like isolates from biofilters as Stenotrophomonas nitritireducens sp. nov., Luteimonas mephitis gen. nov., sp. nov. and Pseudoxanthomonas broegbernensis gen. nov., sp. nov. Int J Syst Evol Microbiol 50, 273-282.

Hiraishi, A. (1988). Respiratory quinoine profiles as tools for identifying different bacterial populations in activated sludge. J Gen Appl Microbiol 34, 39-56.

Huß, V. A. R., Festl, H. \& Schleifer, K. H. (1983). Studies on the spectrophotometric determination of DNA hybridization from renaturation rates. Syst Appl Microbiol 4, 184-192.

Lane, D. J. (1991). 16S/23S rRNA sequencing. In Nucleic Acid Techniques in Bacterial Systematics, pp. 115-175. Edited by E. Stackebrant \& M. Goodfellow. Chichester: Wiley.
Marmur, J. (1961). A procedure for the isolation of deoxyribonucleic acid from microorganisms. J Mol Biol 3, 208-218.

Mesbah, M., Premachandran, U. \& Whitman, W. B. (1989). Precise measurement of the $\mathrm{G}+\mathrm{C}$ content of deoxyribonucleic acid by high-performance liquid chromatography. Int J Syst Bacteriol 39, 159-167.

Saitou, N. \& Nei, M. (1987). The neighbor-joining method: a new method for reconstructing phylogenetic trees. Mol Biol Evol 4, 406-425.

Sasser, M. (1997). Identification of Bacteria by Gas Chromatography of Cellular Fatty Acids. MIDI Technical Note 101. Newark, DE: MIDI.

Smibert, R. M. \& Krieg, W. R. (1994). Phenotypic characterization. In Methods for General and Molecular Bacteriology, pp. 607-654. Edited by P. Gerhardt, R. G. E. Murray, W. A. Wood \& N. R. Krieg. Washington, DC: American Society for Microbiology.

Tamaoka, J. \& Komagata, K. (1984). Determination of DNA base composition by reversed-phase high-performance liquid chromatography. FEMS Microbiol Lett 25, 125-128.

Thierry, S., Macarie, H., lizuka, T. \& 9 other authors (2004). Pseudoxanthomonas mexicana sp. nov. and Pseudoxanthomonas japonensis sp. nov., isolated from diverse environments, and emended descriptions of the genus Pseudoxanthomonas Finkmann et al. 2000 and of its type species. Int J Syst Evol Microbiol 54, 2245-2255.

Wayne, L. G., Brenner, D. J., Colwell, R. R. \& 9 other authors (1987). International Committee on Systematic Bacteriology. Report of the ad hoc committee on reconciliation of approaches to bacterial systematics. Int J Syst Bacteriol 37, 463-464.

Yang, D.-C., Im, W.-T., Kim, M.-T. \& Lee, S.-T. (2005). Pseudoxanthomonas koreensis sp. nov. and Pseudoxanthomonas daejeonensis sp. nov. Int J Syst Evol Microbiol 55, 787-791. 